\title{
PERBAIKAN FUNGSI TROFOBLAST PADA KADAR $\beta$ hCG TIKUS BUNTING PREEKLAMPSIA PADA BAHAN BIOLOGIS TERSIMPAN PASCA PERLKUAN DENGAN SPIRULINA
}

\author{
Adhiono, A. ${ }^{1}$, Gondo, H.K. ${ }^{2}$, Noer Kumala $I^{3}$ \\ ${ }^{2,3}$ Fakultas kedokteran, Universitas Wijaya Kusuma Surabaya \\ e-mail: : noerkumala04176@gmail.com ${ }^{3}$
}

\begin{abstract}
Preeclampsia is multisystem specific disorder in pregnancy. Preeclampsia has signed by increased cytokine Interleukin-6 and $\beta$ hCG (human Chorionic Gonadotropin). Spirulina is green-blue alga has bioactive compound namely antioxidant, vitamin, mineral. And has benefit namely antinflamation. The aim of this research was to know how spirulina influence to repair trophoblast in $\mathrm{Hcg}$ concentration on rat pregnancy (biology material collecting). The type of this research is an experimental laboratoric with post test only control group design. A total of 25 rats with pre-eclampsia models induced by Interleukin 6 are divided into 5 groups: the untreated control group, the positive control group with Interleukin 6 induction for three days, the treatment group with a dose of $10 \mathrm{mg} /$ day, $20 \mathrm{mg} /$ day and $40 \mathrm{mg}$ of spirulina. / day for five day, then the blood serum produced was measured with $\beta$ hCG levels using ELISA (Enzyme-Linked Immunosorbent Assay). The results of the Spirulina 10 $\mathrm{mg} /$ day are higher at $85.11 \pm 25.70 \mathrm{mIU} / \mathrm{ml}$ from a dose of spirulina $20 \mathrm{mg} /$ day at $79.65 \pm 10.65$ $\mathrm{mIU} / \mathrm{ml}$. In the level of $\beta \mathrm{hCG}$, the dose group of spirulina $10 \mathrm{mg} /$ day and the group there is no significant difference (0.730>0.05), the $\beta$ hCG level group of spirulina $40 \mathrm{mg} /$ day was $93.28 \pm 17,12$ $\mathrm{mIU} / \mathrm{ml}$ from the dose group of spirulina $10 \mathrm{mg} /$ day was $85.11 \pm 25.70 \mathrm{mIU} / \mathrm{ml}$. The administration of spirulina for five days was able to reduce $\beta$ hCG levels at a dose of $10 \mathrm{mg} /$ day, $20 \mathrm{mg} /$ day and 40 $\mathrm{mg} /$ day and the dose that was most effective in reducing $\beta$ hCG levels significantly $(P<0.05)$ was a dose of $10 \mathrm{mg}$ than dose of $20 \mathrm{mg} /$ day and $40 \mathrm{mg} /$ day.
\end{abstract}

Keywords: Preeclampsia, Interleukin 6, $\beta$ hCG, Spirulina

\section{PENDAHULUAN}

Salah satu faktor yang merupakan penyulit atau gangguan atau komplikasi yang menyertai ibu saat hamil adalah patologi kehamilan (Sujiyatini,2009). Sekitar lebih dari $63.000 \mathrm{ibu}$ meninggal setiap tahunnya didunia disebabkan preeklampsia. Angka kematian ibu tertinggi terdapat pada negara negara yang berpenghasilan rendah dan menengah, namun demikian preeklampsia juga berpotensi pada negara negara maju (Marie Bolin, 2012). Preeklamsia merupakan gangguan multisistem spesifik pada kehamilan yang ditandai dengan perkembangan hipertensi dan proteinuria (Lana K, 2004). Hingga saat ini preeklampsia masih merupakan "the disease of theories", dimana patofisiologinya masih belum jelas diketahui. Sebagai penanda terjadinya preeklampsia. Pada kasus preeklampsia terjadi peningkatan kadar $\beta$ hCG serum (Priyatini $\mathrm{T}$, 2004).

Human chorionic gonadotropin (hCG) merupakan hormon glikoprotein terdiri dari dua subunit kovalen non , $\alpha$ dan $\beta$, dan diproduksi oleh sel sinsitiotrofoblas plasenta. Puncak dari kadar $\beta$ hCG adalah minggu ke 8 - 10 kehamilan dan kadar paling rendah pada minggu 18 - 20 kehamilan. (Kanika Mandi Chaudhury et all, 2012). Fungsi $\beta$ hCG pada kehamilan adalah sebagai penghasil progresteron, implantasi dan sebagai regulasi sistem kekebalan (W. Norris, 2011).

Spirulina platensis merupakan salah satu varian dari mikroalga Spirulina sp. yang banyak dimanfaatkan oleh masyarakat karena kandungan nutrisinya yang lengkap. (Oliveira et al 2008). Fikosianin merupakan salah satu dari tiga pigmen 
(klorofil dan karotenoid)alami pada spirulina platensis yang bermanfaat sebagai antioksidan (Arlyza, 2005) dan mampu menghambat pembentukan imunomodulator (Adams, 2005). Antioksidan merupakan senyawa pemberi elektron (electron donors) dan secara biologis antioksidan adalah senyawa yang mampu mengatasi dampak negatif oksidan dalam tubuh seperti kerusakan elemen vital sel tubuh. Penelitian menunjukkan bahwa fikosianin dari spirulina berpotensi meningkatkan sistem imun yang mempunyai keuntungan menghambat perkembangan imuomodulator (Pirenantyo, 2008).

Berdasarkan permasalahan tersebut tentang kegunaan spirulina dalam bidang penelitian maka peneliti tertarik untuk melakukan penelitian bagaimana pengaruh spirulina terhadap perbaikan fungsi trofoblast pada kadar $\beta$ hCG tikus bunting preeklampsia pada bahan biologis tersimpan.

\section{METODE PENELITIAN}

Rancangan yang digunakan pada penelitian ini adalah menggunakan rancangan Post Test Only Control Group Design. Desain ini melibatkan subjek secara random pada salah salah satu dari lima kelompok. Tiga kelompok diberi perlakuan dan dua kelompok kontrol; satu dari kelompok perlakuan dan satu dari kelompok kontrol diberi perlakuan eksperimental (Emzir, 2007).

$\mathrm{P} 0=$ Kelompok perlakuan Interleukin 6 dengan dosis $5 \mathrm{mg}$ /hari (i.v).

P1 = Kelompok perlakuan Interleukin 6 (i.v) dan Spirulina dengan dosis $10 \mathrm{mg} /$ hari per oral.

P2 = Kelompok perlakuan Interleukin 6 (i.v) dan Spirulina dengan dosis $20 \mathrm{mg} /$ hari per oral.

P3 = Kelompok perlakuan Interleukin 6 (i.v) dan Spirulina dengan dosis $40 \mathrm{mg} /$ hari per oral.

Penelitian ini menggunakan ELISA Reader dengan metode Sandwich untuk mengukur $\beta$ hCG maka dari itu menggunakan antigen berupa serum $\beta$ hCG dan antibody yaitu anti-hCG (Mab). Tujuan dari mertode ini adalah untuk mengukur kadar antigen yaitu $\beta$ hCG yang terdapat pada serum.
Cara kerja ELISA pada penelitian ini diawali dengan (1) proses tawing yaitu pengenceran serum yang ada didalam mikrotube yang sebelumnya disimpan dilemari es. (2) Memasukkan serum tersebut kedalam microplate sebanyak $50 \quad \mu$ Lsetiap kelompok 5 lubang microplate. (3) Masukkan $100 \mu \mathrm{L}$ hCG Kit yaitu anti-hCG (Mab) kesemua microplate, (4) tutupi mikroplate dan inkubasi selama 60 menit dengan temperatur ruangan $\left(18-26^{\circ} \mathrm{C}\right),(5)$ bersihkan semua serum/cairan dari mikroplate dengan cara dibilas menggunakan buffer dan letakkan kertas blot/absorbent. (6) tambahkan $100 \mu \mathrm{L}$ TMB substrat kesemua mikroplate. (7) inkubasi selama 10 menit pada temperatur ruangan. Tambahkan $50 \mu \mathrm{L}$ stop solution pada semua microplate, aduk hingga mencampur (9) Baca absorbansi pada ELISA reader $450 \mathrm{~nm}$ dalam waktu 15 menit setelah stop solution diberikan (Sigma Aldrich, 2014).

\section{HASIL PENELITIAN}

\section{A. Analisa $\beta$ hCG setelah diinduksi Interleukin-6}

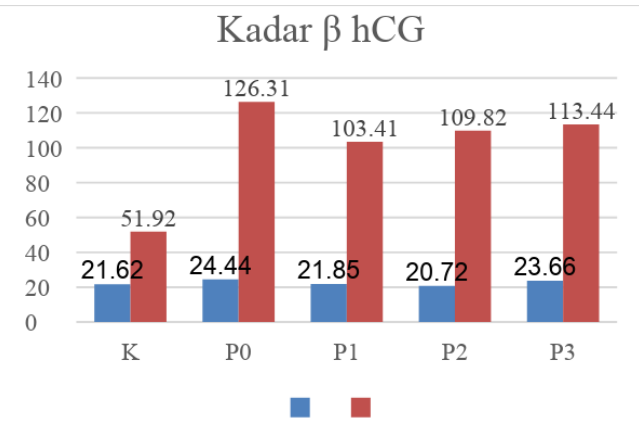

Hasil tersebut menunjukan bahwa induksi Interleukin-6 dengan dosis $5 \mathrm{mg} / \mathrm{hr}$ selama 3 hari mampu meningkatkan kadar $\beta$ hCG dari kelompok P0 sebelum diinduksi Interleukin-6 sebesar 24,44 $\pm 6,49 \mathrm{mIU} / \mathrm{ml}$ menjadi $126,31 \pm 47,09 \mathrm{mIU} / \mathrm{ml}$ setelah diinduksi Interleukin 6. Pada kelompok P1 
sebelum diinduksi Interleukin 6 sebesar 21,85 $\pm 3,23 \mathrm{mIU} / \mathrm{ml}$ menjadi $103,41 \pm 28,30$ $\mathrm{mIU} / \mathrm{ml}$ setelah diinduksi Interleukin 6. Pada kelompok P2 sebelum diinduksi Interleukin 6 sebesar 20,72 $\pm 4,98 \mathrm{mIU} / \mathrm{ml}$ menjadi 109.82 $\pm 20.87 \mathrm{mIU} / \mathrm{ml}$ setelah diinduksi Interleukin6.

Pada kelompok Dosis P3 sebelum diinduksi Interleukin- 6 sebesar 23,66 \pm 4,98 $\mathrm{mIU} / \mathrm{ml}$ menjadi $113,44 \pm 20,18 \mathrm{mIU} / \mathrm{ml}$ setelah diinduksi Interleukin- 6.

\section{B. Analisa kadar $\beta$ hCG setelah pemberian Spirulina yang diinduksi Interlekin 6}

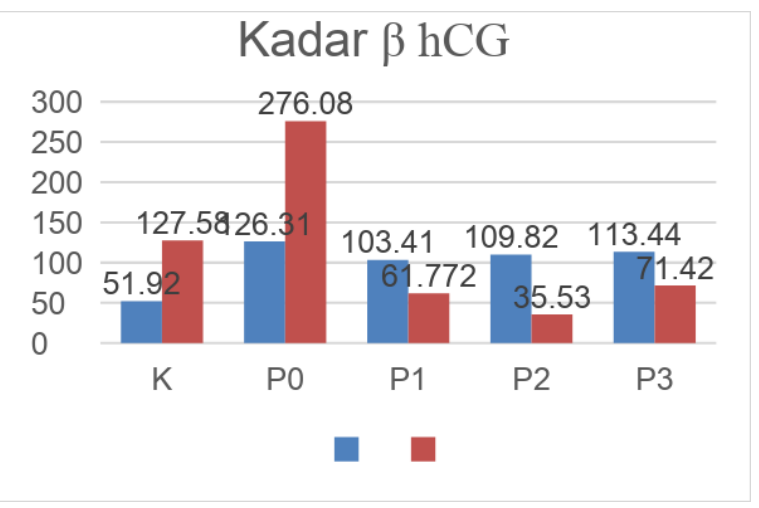

Hasil tersebut menunjukan bahwa pemberian spirulina dengan dosis $10 \mathrm{mg} / \mathrm{hr}$, dosis $20 \mathrm{mg} / \mathrm{hr}$, dan dosis $40 \mathrm{mg} / \mathrm{hr}$ selama 5 hari mampu menurunkan kadar $\beta$ hCG. Pada kelompok P1 sebelum diberi spirulina sebesar $103,41 \pm 28,30 \mathrm{mIU} / \mathrm{ml}$ menjadi $61,772 \pm$ $18,44 \mathrm{mIU} / \mathrm{ml}$ setelah diberi spirulina. Pada kelompok P2 sebelum diberi spirulina sebesar $109.82 \pm 20.87 \mathrm{mIU} / \mathrm{ml}$ menjadi $35,53 \pm 8,61$ $\mathrm{mIU} / \mathrm{ml}$ setelah diberi spirulina. Pada kelompok P3 sebelum diberi spirulina sebesar $113,44 \pm 20,18 \mathrm{mIU} / \mathrm{ml}$ menjadi 71,42 $\pm 15,99$ $\mathrm{mIU} / \mathrm{ml}$ setelah diberi spirulina.

\section{DISKUSI}

\section{A. Pengaruh Interleukin 6 pada kadar Hcg tikus bunting putih}

Penelitian ini menggunakan 25 ekor tikus putih bunting dilakukan dengan cara diinduksi Interleukin 6 dengan dosis $5 \mathrm{mg}$ selama 3 hari untuk menjadikan model preeklampsia, analisa $\beta$ hCG dilakukan untuk mengetaui peningkatan kadar hcg. Menurut penelitian Gadonski et all, 2006 penambahan Interleukin 6 mampu meningkatkan tekanan darah dan meningkatkan sitokin proinflamasi TNF alfa dan GFR. Menurut penelitian (Gokdeniz et all, 1999) Pada 3 wanita yang preeklaampsia didapatkan peningkatan $\beta$ hCG dari pada wanita yang tidak preeklampsia. Hasil penelitian tersebut sesuai dengan penelitian ini bahwa pemberian Interleukin 6 dengan dosis $5 \mathrm{mg}$ selama 3 hari mampu meningkatkan kadar kadar $\beta$ hCG dari 22,66 $\pm 42,7 \mathrm{mIU} / \mathrm{ml} \mathrm{ke} 113,24 \pm 29,11 \mathrm{mIU} / \mathrm{ml}$ $(0,001<0,005)$.

\section{B. Penngaruh spirulina terhadap kadar $\beta$ hcg pada tikus putih bunting yang terinduksi Interleukin 6}

Spirulina adalah mikroalga yang memiliki cyanobacterium mikroskopik berfilamen, mengandung bahan C-fikosianin yang merupakan zat dengan aktivitas kemopreventif kanker yang poten (Ravi M et al, 2010). Zat ini mampu menginduksi apoptosis dengan cara memfragmentasi DNA dan kondensasi nukleus. Penelitian yang lain menyebutkan bahwa Cfikosianin dari spirulina memiliki kemampuan untuk menurunkan regulasi protein anti apoptosis dan meningkatkan regulasi protein proapoptosis 
(Belay A, 2002), juga mempunyai fungsi sebagai antioksidan yang mampu menghambat perkembangan imunomodulator (Arlyza, 2005; Adams, 2005).

Hasil penelitian ini menunjukkan bahwa pemberian spirulina dengan kadar $\beta$ hCG kelompok P1 tidak berbeda signifikan dengan kelompok Dosis $20(0,537>0,05)$, kadar $\beta$ hCG P1 lebih tinggi yakni $61,772 \pm 18,44 \mathrm{mIU} / \mathrm{ml}$ dari $\mathrm{P} 2$ sebesar 35,53 $\pm 8,61 \mathrm{mIU} / \mathrm{ml}$. Pada Kadar $\beta$ hCG kelompok P1 dan Kelompok P3 tidak terdapat perbedaan signifikan $(0,820>0,05)$, kadar $\beta$ hCG Kelompok P3 lebih tinggi yakni 61,772 $\pm 18,44$ $\mathrm{mIU} / \mathrm{ml}$ sedangkan Kelompok P1 sebesar 71,42 \pm $15,99 \mathrm{mIU} / \mathrm{ml}$.

\section{Dosis Efektif Spirulina}

Sampel terdiri atas 24 ekor tikus jantan dipilih dengan cara random sampling untuk dibagi dalam. Dalam penelitian ini pemberian spirulina diberikan dalam 3 dosis bertingkat yaitu $10 \mathrm{mg} / \mathrm{hr}$, $20 \mathrm{mg} / \mathrm{hr}$, dan $40 \mathrm{mg} / \mathrm{hr}$. dari ketiga dosis spirulina yang diberikan tersebut didapatkan hasil dosis efektif yaitu $10 \mathrm{mg}$ karena pada dosis tersebut sudah dapat menurunkan kadar $\beta$ hCG secara efektif dibanding spirulina dosis $20 \mathrm{mg}$ dan $40 \mathrm{mg}$ karena pada antioksidan pada dosis berlebih akan menjadi radikal bebas yang dapat berbahaya bagi kesehatan.

Menurut penelitian Kansas State University tahun 2010 mengatakan bahwa penambahan antioksidan dalam jumlah berlebih fungsinya tidak lagi menjadi antioksidan, melainkan menjadi prooksidan, Sehingga Spirulina yang berfungsi sebagai antioksidan menjadi radikal bebas yang dapat merusak trofoblas dan uterus. Dalam penelitian Spirulina dalam dosis $20 \mathrm{mg} / \mathrm{hr}$ dan 40 $\mathrm{mg} / \mathrm{hr}$ menjadi prooksidan karena dosisnya belebih sehingga dapat menurunkan kadar $\beta$ hCG tetapi tidak signifikan.

\section{KESIMPULAN}

1. Pemberian Interleukin-6 dengan dosis $5 \mathrm{mg}$ selama 3 hari pada tikus bunting mampu meningkatkan kadar $\beta$ hCG secara signifikan $(\mathrm{P}<0,05)$ yakni dari $22,66 \pm 42,7 \mathrm{mIU} / \mathrm{ml} \mathrm{ke} 113,24 \pm 29,11$ $\mathrm{mIU} / \mathrm{ml}$.

2. Pemberian Spirulina selama 5 hari mampu menurunkan kadar $\beta$ hCG secara signifikan yakni dari $108,89 \pm 23,11$ $\mathrm{mIU} / \mathrm{ml} \mathrm{ke} 56,24 \pm 14,34 \mathrm{mIU} / \mathrm{ml}$.

3. Dosis efektif Spirulina adalah $10 \mathrm{mg}$ karena Kadar $\beta$ hCG lebih rendah dari kelompok Dosis $10 \mathrm{mg}$ dan Dosis $40 \mathrm{mg}$.

\section{DAFTAR PUSTAKA}

Adiyati PN. 2011. Ragam jenis ektoparasit pada hewan coba tikus putih (Rattus norvegicus) galur Sprague dawley. Skripsi. Bogor: Fakultas Kedokteran Hewan Institut Pertanian Bogor.

Amha Belay. 2002. The Potential Application of Spirulina (Arthrospira) as a Nutritional and Therapeutic Supplement in Health Management. The Journal of the American Nutraceutical Association Vol 5, no 2, Spring

Asanoma K, Kubota K, Chakraborty D, Renaud SJ, Wake N, Fukushima K, Soares MJ, Rumi MA. SATB homeobox proteins regulate trophoblast stem cell renewal and differentiation. J Biol Chem. 2012;287: 2257-2268.

Arylza, I.S. 2005.Phycocyanin dari Mikroalga Bernilai Ekonomis Tinggi sebagai Produk Industri.Oseana.XXX(3): 27-36.

Bolin, marie. 2012. Pre-eklampsia - possible to predict?. Acta Universitatis Upsaliensis. Digital Comprehensive Summaries of Uppsala Dissertations from the Faculty of 
Medicine 835. 66 pp. Uppsala. ISBN 97891-554-8523-8.

Boussiba, S. and Richmond, A. 1979.Isolation and Purification of Fikosianin from The Blue Green Alga Spirulina platensis. Arch. Microbiol., 120: 155-159.

Casey ML, Mac Donald DC, Simpson ER. Endocrinological changes of pregnancy. IN : Williams text book of endocrinology. 8th ed. WB. Saunders Co. 1992 : 987 - 89.

Cunningham, F.G,. 2005. Obstetri Williams:

Gangguan Hipertensi dalam Kehamilan.

Edisi 21. Jakarta: EGC, 624-640.

Emzir. 2007. Metodologi Penelitian Pendidikan

Kuantitatif dan Kualitatif. Jakarta: PT Raja Grafindo Persada.

Fisher DA. Endocrinology of fetal development In: Williams text book of endocrinology. 8 th ed. WB. Saunders Co. Philadelpia, 1992 : $1049-71$.

Galazios, G., Tsoulou, S., Zografu,C.,Tripisianis, G., Koutlaki, N., Papazoglou,D., Tsikouras, P., Maltezos, E., and Liberis, V., 2011,The role of cytokines IL-6 and IL-8 in the pathogenesis of spontaneous abortions. The Journal of Maternal-Fetal \& Neonatal Medicine vol24 (10)hal 1283-1285

Ganong,W.F. 2008. Buku Ajar Fisiologi Kedokteran. Jakarta: EGC

Giovani Gadonski. 2006. Hypertension Produced by Reductions in Uterine Perfusion in the Pregnant Rat Role of Interleukin 6. Departments of Physiology and ObstetricsGynecology and Center for Excellence in Cardiovascular-Renal Research, University of Mississippi Medical Center, Jackson, Miss.pages 711-715

Gökdeniz, R.; Ariguloglu, E.; Bazoglu, N. \& Balat, Ö. Elevated serum b-hCG levels in severe preeclampsia. Turk. J. Med. Sci.,30(1):43-6, 2000
Guerin, L.R., Prins, J.R., Robertson, S.A., 2009. Regulatory T-cells and immune tolerance in pregnancy: a new target for infertility treat-ment? Hum. Reprod. Update 15, 517 535.

Hall DO, Rao KK. 1999. Photosynthesis six edition. Cambridge: Cambridge university press

Hery Winarsi, Antioksidan Alami dan Radikal Bebas, (Yogyakarta: Kanisius, 2007), hlm. 17

Jaringan Nasional Pelatihan Klinik-Kesehatan Reproduksi. 2007. Asuhan persalinan Normal \& Inisiasi Menyusu dini. Jakarta: JNPK-KR

Jongkon P., Siripen T dan Richard D. L. 2008. Phytoremediation of Kitchen Wastewater by Spirulina platensis (Nordstedt) Geiteler: Pigment content, Production Variable Cost and Nutritonal Value. Maejo International Journal of Science and Technology. Vol. 2 No. 02 hal. 159 - 171.

Jürgen Scheller et all. 2011. The pro- and antiinflammatory properties of the cytokine interleukin-6. Biochimica et Biophysica Acta (BBA) - Molecular Cell Research Volume 1813, Issue 5, May 2011, Pages 878-888

Kabede,E and Ahlgren, G. 1996. Optimum Growth Conditions and Light Utilization Efficiency of Spirulina platensis (Arthospira fusiformis) from Lake Chitu, Ethiopia. Hydrobiol., 332:99---109.

Kabinawa, I.N.K. 2001. Mikroalga sebagai Sumber Daya Hayati (SDH) Perairan dalam Perspektif Bioteknologi. Puslitbang Bioteknologi Lembaga Ilmu Pengetahuan. Bogor

Kanika Mandi Chaudhury „Munmun Das, Sulekha Ghosh, Debasis Bhattacharya, Tapan Kumar Ghosh : Value of serum beta hcg in 
pathogenesis of preeclampsia. Journal of clinical Gynaecology and obstetrics.volume 1, number 4-5, oct. 2012, pg 71-75

Kansas State University. 2010. Study shows potential negative from antioxidants. US: Lifelines vol 5 No.2.

Karen A, Williams H, Decherney AH. The endocrinology of pregnancy. In: Medicine of fetus \& mother. JB Lippincott Co. Philadelpa 1992: 97 - 116.

Kishimoto,, T. 2005. Interleukin-6: from basic science to medicine- 40 years in immunology. Annu. Rev. Immunol.

Kozlenko, R, dan Henson, RH. 1998. Spirulina: Effects on the AIDS Virus, Cancer and the Immune System. Spirulina Health Library.www. Spirulina.com. (1 Nopember 2000).

LaMarca B, Brewer J, Wallace K. IL-6-induced pathophysiology during pre-eclampsia: potential therapeutic role for magnesium sulfate? International journal of interferon, cytokine and mediator research: IJIM. 2011;2011(3):59-64. doi:10.2147/IJICMR.S16320.

Liu Y, Lizhi X, Cheng N, Lin L, Zhang C. 2000. Inhibitory effect of phycocyanin from Spirulina platensis on the growth of human leukemia K562 cell. Applied Phycology 12:125-130

Lunghi et al. 2007. Control of human trophoblast function.Reprod Biol Endo.5:1477-7827.

M. A. Borowitzka and L. J. Borowitzka. 1988. Micro-algal biotechnology. Cambridge: Cambridge University Press

Masojidek, J., M. Koblizek, and G. Torzillo. 2004. Photosynthesis in Microalgae in: A. Richmond (Ed). Handbook of Microalgal Culture: Biotechnology and Applied Phycology. Blakwell Science Ltd., Iowa. p.20-39.
Mochtar Rustam. Sinopsis Obstetri jilid 1: Obstetri Fisiologi, Obstetri Patologi. 2nd ed. Jakarta: EGC; 1998. p35-59.

Oliveira EG, Rosa GS, Moraes MA, Pinto LAA. 2008. Phycocyanin Content of Spirulina platensis dried in spouted bed and thin layer. Journal of Food Process Engineering, 31(1): 34-50.

Pamungkas, A. 2005. Sistem Taksonomi hewan dan tumbuhan. ANDI, Bandung.

Perubahan Anatomi pada Ibu Hamil Tiap Trimester [Internet]. Semarang: Jurnal Bidan Diah; 2012 [updated 2012 Nov 15; cited 2012 Dec 3]. Available from: http://jurnalbidandiah.blogspot.com/2012/ 11/perubahan-anatomi-pada-ibu-hamiltiap_2825.html

Pirenantyo, p., Limantara, L. 2008. PIGMEN SPIRULINA SEBAGAI SENYAWA ANTIKANKER. Magister Biologi Universitas Satya Wacana.

Prawirohardjo, S. Fisiologi Kehamilan, Persalinan, Nifas, dan Bayi Baru Lahir. In: Saifuddin AB, Wiknjosastro GH (eds.) Ilmu Kebidanan. 4th ed. Jakarta: PT Bina Pustaka Sarwono Prawirohardjo; 2008. p174-187.

Priyambodo. 2003. Pengendalian Hama Tikus Terpadu. Penebar Swadaya.Jakarta.

Priyatini T, Wiknjosastro GH. 2004. Angka Kejadian Preeklampsia Berat dan Eklampsia di Rumah Sakit Umum Pusat Cipto Mangunkusumo Jakarta

Ravi $\mathrm{M}$ et all. 2011. The beneficial effects of spirulina focusing on its immunomodulatory and antioxidant properties. Department of Human Genetics,Faculty of Biomedical Sciences,Technology and Research, Sri Ramachandra University,Porur, Chennai, India 
Robinson. 1979. Taxonomi and genetic. in Beker HJ,LindsayJR, and WeisbrothS, editor. The LaboratoryRat. London (GB): Academic Pr.

Sarada, R., M.G. Pillai, dan G.A. Ravishankar. 1999. Phycocyanin from Spirulina sp.: Influence of Processing of Biomass on Phycocyanin Yield, Analysis of Efficiency of Extraction Methods and Stability Studies on Phycocyanin. J. Proc. Biochem. 34:795801.

sigma-Aldrich Co. LLC. 2014. Human Chorionic Gonadotropin (hCG) ELISA. US

Sirois, 2005, Laboratory Animal Medicine: Principles and Procedures, Elsevier,USA.

Sujiyatini, dkk. 2009. Asuhan Patologi Kebidanan. Jakarta: Nuha Medika.

Wagner, Lana K. 2004. Diagnosis and Management of Preeclampsia. Mexico: Diagnosis and Management of Preeclampsia

Wendy Norris, et all. 2011. Review: Hcg, Preeclampsia and Regulatory T cells. NIH Public Access: Department of Pediatrics, Women and Infants Hospital-Warren Alpert Medical School of Brown

University, Providence, Rhode Island, USA

Yaron Y, Cherry M, Kramer RL et al. Maternal serum fetoprotein, hCG, estriol and their various combinations as predictors of pregnancy outcome. Am J Obstetgynecol 1999; 181; $968-74$

Yasa GP. Peranan peroksidase lipid pada patogenesis preeklampsia. Bali: Bagian Obstetri dan Ginekologi FK Unud/RSUP Sanglah Denpasar; 2013. 
Medical and Health Science Journal, Vol. 2, No. 2, August 2018 